\title{
OUTSTANDING ISSUES OF MOTOR CAR RECYCLING IN TERMS OF ENVIRONMENTAL IMPACT MITIGATION
}

\author{
Tomasz SŁOWIK ${ }^{1}$, Andrzej KURANC ${ }^{1}$, Jacek WASILEWSKI ${ }^{1}$, \\ Grzegorz ZAJĄC ${ }^{1}$, Agnieszka DUDZIAK ${ }^{1}$, Michal HOLUBCIK ${ }^{2}$ \\ ${ }^{1}$ University of Life Sciences in Lublin, POLAND \\ ${ }^{2}$ University of Zilina, SLOVAKIA \\ E-mail of corresponding author: tomasz.slowik@up.lublin.pl
}

Keywords: recycling, motor car, LPG, CNG, sustainable development

\begin{abstract}
Due to the intensive growth of the importance of all activities in the field of ecology and rational economy, the article presents an attempt to develop a comprehensive model of the dehumidification process of LPG and CNG gas cylinders. The recovery of the gases from gas cylinders in the circumstances of the Polish economy will lead to an improvement of the work and environmental safety and to increase the recovery rates.
\end{abstract}

\section{INTRODUCTION}

Changes in the construction of agricultural working machines and vehicles, and improving recycling techniques affect the growth of the importance of product recycling at the expense of energetic recycling, which is less economically viable.

Due to the fact that recycling issues are of great ecological, economic and material importance, it is necessary to adopt a global policy to increase the relevance of that issue. It is also important to include issues related to the forecasting and controlling of recycling processes, depending on the amount and type of utility waste and the technologies and applications used in the country (Gaballah I. Kanari N. 2001, Upper Z., Sobczak J. 1995, Mc Donough WJ 1994, Schuster D.M. et al. 1993).

Efficient disposal management of solid waste arising from any type of motor cars in Poland is still an outstanding issue, although first acts of law regarding motor cars were enforced in 2005. Imprecise and amended law and related regulations still fail to effectively address the aforementioned outstanding issue, and inaction will result in deterioration of living standards for the contemporary civilisation, damage of natural environment and landscape as well as development of civilisation disease.

The essence of recycling is most of all withdrawal of a variety of natural resources from operational use in the manner that will ensure the maximum shortening of the technological cycle of products - which is driven by economics - and mitigation of hazards in reuse - which is driven by ecology (Wojciechowski 2012). The said measures should aim at the ,closed-loop material cycle”, for instance, that is an economic objective and should be subject to the following criteria, according to Wojciechowski (2012):

- development of the recycle and recover technology at the stage of designing,

- solid waste prevention in the production or manufacturing processes,

- promotion of low-emission and waste-free production,

- it should aim eventually at energy recovery,

- development of safe technologies for hazardous substances,

- improvement of unification and cohesion of solid waste disposal management law and related regulations, 
- development of the comprehensive education programme.

Given the current automotive industry growth forecast, there is an imminent need for improvement of any of the recycling system elements. According to the figures published by the Central Statistical Office (Transport 2001) it is estimated that in 2020 approximately one billion of motor cars will be driven on Earth and 30 years later this number will double.

Further to the above, the related literature more and more frequently refers to varied strategic approaches to the recycle management (Merkisz-Guranowska 2005, Tomczyk 2005, 2006 and 2009, Wojciechowski 2012, Wojcieszak 2012), that aim at substantial improvement of recycle and recovery efficiency in terms of their broad meaning from the point of view of both comprehensive and primary targets.

\section{STUDY OBJECTIVE AND SUBJECT MATTER}

The study objective is to present the scale of the outstanding issue of the recycle of LPGdriven and CNG-driven motor cars in terms of systemic drying cylinders out of fuel for the purpose of subsequent recycling.

Procedures of improvement of efficiency of drying and re-classifying solid waste such as LPG and CNG cylinders, originating from motor cars withdrawn from the road, constitute the subject matter of the study.

The authorities of European countries have set up institutions that take care to reduce waste and air pollution and minimize energy consumption. These efforts are aimed at rational exploitation of human and material resources by the promotion of sustainable development and the reduction of disparities in that matter between the world economies, ie the EU, Japan and the United States.

Given the observation of Lublin industry sector dealing with disassembly of motor cars, among others, the increasing size of the problem of recycling mainly LPG cylinders and few CNG cylinders draws attention. This was confirmed by the surveys conducted in the period from 2012 until 2014 among 9 vehicle disassembly stations located in the Lublin Region. None of the surveyed vehicle disassembly stations was equipped with a drying device for this type of gas cylinders, and each of them collected from 350 to $470 \mathrm{~kg}$ of liquid gas cylinders of 160116 waste code classified as hazardous solid waste on the annual basis. The price and the impossibility to neutralise such a cylinder to classify it as 160117 waste code pertaining to ferrous metal, after having dried it, are the major reasons for the failure for vehicle disassembly stations to be equipped with drying devices for gas fuel.

In the Polish market two drying devices for LPG and CNG cylinders originating from motor cars withdrawn from the road are available to be compliant with the standards governed by Directive 2000/53/CE:

- manual ones, in the case of which an employee needs to make all necessary connections and run the process of draining gas out of a cylinder and nitrogen rinsing of a cylinder as well as burning this mixture in a torch (the cost of such a device amounts to PLN 35 000),

- automatic ones in which subsequent processes are independently run after a cylinder is placed in a chamber (the cost of such an automatic drier amounts approximately to PLN 75 000). 
A drier pumps LPG out of a motor car cylinder into a standard cylinder, for instance of $11 \mathrm{~kg}$ in weight, and concurrently runs nitrogen rinsing of a cylinder. In the case of CNG, it is just possible to burn gas out in a torch. Such a system allows gas to be removed from a motor car cylinder as well as to get rid of remaining gas by means of controlled burning. In the course of emptying a cylinder, it is concurrently being nitrogen-rinsed, nitrogen being supplied from an external source. The aforementioned process allows motor car cylinders to be recovered in conformity with law and related regulations.

The advantage of such a device - when you have come into possession of it - is the opportunity to use LPG that has been pumped out, for instance as fuel for fork lifts or heating halls in the winter season. It is vital that well-trained personnel is exclusively authorised to operate this type of devices.

There are few enterprises that render services of reclassifying gas cylinders, which is automatically making them eligible for scrapping cylinders and recovering ferrous metal under the solid waste code 160117 . The cost of such services ranges from the net amount of PLN 5 to 10 per cylinder - depending on the number of cylinders supplied, furthermore a vehicle disassembly station loses scrap metal, fuel and incurs expenses on top of that which is discouraging. In the case of not more than 50 cylinders, those prices are normally higher. Since the number of cylinder that a vehicle disassembly station obtains is usually not more than 20 gas cylinders per annum, higher costs brings about bad practices such as discharging gas or pumping it into other cylinders by means of forbidden or hazardous procedures. Even when a vehicle disassembly station resolves to deliver cylinders of the solid waste code 160116 down to such an enterprise, it may face being charged with hazardous waste transport irregularities. In consequence, such a type of practices bring about considerable hazards arising from seemingly dried cylinders that still contain vestigial quantity of gas and are transported with other scrap metal by means of transport that are not fit for that purpose. Given the above, the figures of the quantity of recovered LPG are imprecise.

Taking into consideration the fact that motor cars dating back to the period of boom in gas installations in Poland - namely the period from 1994 until 2004 - are only now beginning to be delivered to vehicle disassembly stations and the fact that gas installations are becoming more and more popular, the number of recycled LPG cylinders may be expected to double or triple. CNG has only recently begun to develop mainly to the intention to generate savings in the urban passenger transport services in larger cities and in some of commodity transport sectors. Given all the vehicle types registered in Poland in the number of 23 million (Wheeled Transport 2015), LPG-driven vehicles account for 13\%: passenger cars - 2,8 million, trucks - 0,18 million, truck tractors - 0,0015 million, buses - 0,0008 million, special vehicles - 0,0038 million.

According to the forecast by the National Solid Waste Disposal Management Plan (2002), in 2006 in Poland approximately 0.5 million of motor cars withdrawn from the road should have been recycled on the annual basis, and only 0.15 million of them were actually recycled. We currently recycle 0.4-0.5 million of motor cars withdrawn from the road on the annual basis (Statystyki according to SI CEPIK 2015), and as the forecast suggests we should recycle approximately 0,8 million of motor cars withdrawn from the road on the annual basis. So, from the statistical point of view, each vehicle disassembly station in Poland should process approximately 750 of motor cars withdrawn from the road on the annual basis, and the surveyed stations in the Lublin region recycle as little 
as $20 \%$ of that number (Table 1.). Furthermore, two out of the surveyed vehicle disassembly stations operating in Lublin wound up their business operations in 2014. It is the consequence of numerous problems that, according to Wojcieszak (2012), have come hitherto down in Poland - as far as the recycling of motor cars withdrawn from the road - to: illegitimate disassembly of used motor cars in the grey market, inefficient system of disassembly subsidies, difficulties in obtaining recovery and recycle certificates as well as falling prices of recycled materials in result of the financial crisis - which directly influences profitability of the recycling business model.

Table 1. Exemplified quantity of solid waste originating from disassembly of motor cars subject to recycling of products or materials, according to the figures available from vehicle disassembly stations on the annual basis (own paper on the grounds of Marczuk et al. 2015)

\begin{tabular}{|c|c|c|c|}
\hline \multirow[b]{2}{*}{ Type of Solid Waste } & \multirow{2}{*}{$\begin{array}{l}\text { Weight of Solid Waste } \\
{[\mathrm{Mg}]}\end{array}$} & \multicolumn{2}{|c|}{ Weight of Solid Waste Subject to: $[\mathrm{Mg}]$} \\
\hline & & $\begin{array}{l}\text { Recycling of } \\
\text { Products }\end{array}$ & $\begin{array}{l}\text { Recycling of } \\
\text { Materials }\end{array}$ \\
\hline Plastic & 7.435 & 0.624 & 6.811 \\
\hline Glass & 3.426 & 0.41 & 3.016 \\
\hline LPG Cylinders & 0.432 & 0 & 0.432 \\
\hline
\end{tabular}

According to Wojcieszak (2012) there are also at least three reasons for that state of play that vehicle disassembly stations cannot be blamed for:

- no relevant supervision of the state authorities over their operations and competence overlap among numerous institutions in that respect,

- dramatically high and relatively continual growth of imports of used motor cars from abroad with the concurrent decrease in the number of new cars bought,

- dramatically high and relatively continual fall of expenditures incurred on research and development, which causes sluggishness in that field.

Rising costs of recycling due to dispersed automotive industry are also indicated by Romański and Kowalczyk (2010).

\section{CONCLUSIONS}

The aforementioned problems with drying LPG and CNG cylinders also incorporate themselves into the inaccessibility of relevant systems and technologies of specific types of solid waste disposal management, which is underlined by Wojciechowski (2012).

In the case of problems with gas cylinder drying, one should comply with the strategy recommended by a number of authors in respect of operations of vehicle disassembly stations in terms of the recycling system as a whole in Poland (Wojciechowski 2012, Merkisz-Guranowska 2005).

The research that has been conducted in recent years indicates a number of conclusions and procedures in connection with intended research on LPG and CNG cylinder recycling:

- establishment of 4 or 5 gas cylinder drying mobile centres in Poland, that will leave scrap metal and recovered fuel with vehicle disassembly stations, possible 
implementation of co-financing programmes coming forward with financial assistance of $70 \%$ to be allocated to the acquisition of drying devices,

- marketability of recovered LPG, which may additionally increase financial gains of vehicle disassembly stations; stations may use recovered gas for their own purposes.

Implementation of the above will have a positive impact upon the indicators of the sustainable development in its broad sense:

- economics - increasing the quality of generating units will allow to enjoy a better price and consequently improve financial figures;

- law and administration - the obligation to increase the percentage share of recycled materials;

- $\quad$ sociology - ecological awareness rising;

- engineering - the BRD rise linked with newer motor cars driven on our roadways, equipped with active and passive safety devices in terms of standard equipment, that also give feedback to safety measures when it comes to the roadway engineering infrastructure.

Moreover, as the rise in the complexity of the materials and systems used also in agriculture, new technologies to ensure sustainability and high recycling rate of such components, machines and vehicles will be required (Jody B. J. et all 2010).

\section{REFERENCES}

Gaballah, I. Kanari, N. (2001). Recycling Policy in the European Union. JOM, 24-27.

Górny, Z., Sobczak, J. (1995). Metal Matrix Composites Fabricated by the Squeeze Casting Process. Transaction of the Foundry Research Institute, XLV(42), Special issue, 99.

Jody, B. J., Daniels, E. J., Duranceau, C. M. Pomykala, J. A., Spangenberger, J. S. (2010). End of-Life Vehicle Recycling: The State of the Art of Resource. Recovery from Shredder Residue. Center for Transportation Research Energy System Division, Aragonne National Laboratory. ANL/ESD/07-8.

Krajowy Plan Gospodarki Odpadami. Ministerstwo Środowiska 2002.

Marczuk, A., Misztal, W., Słowik, T., Piekarski, W., Bojanowska, M., Jackowska I. (2015). Chemiczne uwarunkowania zagospodarowania elementów pojazdów poddanych recyklingowi. Przemyst Chemiczny 10, DOI 10.15199/62.2015.10.46, 1860-1871.

Mc Donough, W. J. (1994). Advanced Materials, Annual Report. U.S. Department of the Interior, Bureau of Mines, 57.

Merkisz-Guranowska, A. (2005). Aspekty rozwoju recyklingu w Polsce. Wydawnictwo Instytutu Technologii Eksploatacji. Radom.

Romański, L., Kowalczyk, M. (2010). Ocena procesu odzysku wybranych odpadów pochodzących z eksploatacji pojazdów samochodowych na przykładzie przedsiębiorstwa Moto-Pols. Inżynieria Rolnicza, 2(120), 149-156.

Schuster D.M. et al. (1993). The Recycling and Reclamation of Metal-Matrix Composites. Journal of Metals, 26-30.

Statystyki z SI CEPiK. Pojazdy wyrejestrowane za lata 2007-2014. http://www.cepik.gov.pl/statystyki. 2015.

Tomczyk, W. (2005). Problemy organizacyjno-prawne recyklingu maszyn i pojazdów w aspekcie przystąpienia Polski do Unii Europejskiej. Inżynieria Rolnicza. No 7 (67), 349-357. 
Tomczyk, W. (2006). System odnowy maszyn rolniczych w aspekcie poszanowania środowiska. Inżynieria Rolnicza. 12(87), 511-517.

Tomczyk, W. (2009). Wycofywanie pojazdów i maszyn rolniczych w aspekcie ochrony środowiska. Inżynieria Rolnicza. 8(117), 243-249.

Transport drogowy w Polsce w latach 2012 i 2013. GUS, (2015).

Transport. Wyniki działalności w 2000 roku, GUS, (2001).

Wojciechowski, A. (2012). Recykling samochodów. Materiały i technologie odzysku. Wydawnictwo ITS Warszawa.

Wojcieszak, A. (2012). Główne cele rozwoju krajowego systemu demontażu samochodów wycofanych z eksploatacji. Studia i Prace Wydziału Nauk Ekonomicznych i Zarzadzania, 30. Wydawnictwo Naukowe Uniwersytetu Szczecińskiego, 261-270. 